\title{
Retraction: Effect of controlled and uncontrolled cooling rate on motility parameters of cryopreserved ram spermatozoa
}

Iraj Ashrafi ${ }^{*}$, Hamid Kohram ${ }^{2,3}$, Hamid Naijan ${ }^{2}$, Majid Bahreini ${ }^{4}$ and Hamid Mirzakhani ${ }^{4}$

\section{Retraction}

This article [1] has been retracted at the request of the Editor. Although the authors withdrew their submission in order to publish elsewhere, the article was subsequently transmitted to the journal's production department which resulted in it being published in error.

\footnotetext{
Author details

'Young Researchers Club, Science and Research Branch, Islamic Azad University, Tehran, Iran. ${ }^{2}$ Department of Animal Science, Faculty College of Agriculture and Natural Resources, University of Tehran, Karaj, Iran.

${ }^{3}$ Department of Clinical Sciences, Faculty of Veterinary Medicine, Shahid

Chamran University, Ahvaz, Iran. ${ }^{4}$ Animal Breeding Center of IRAN, Karaj, Iran.
}

Received: 10 April 2012 Accepted: 10 April 2012

Published: 21 June 2012

\section{Reference}

1. Iraj Ashrafi, Hamid Kohram, Hamid Naijian, Majid Bahreini, Hamid Mirzakhani: Effect of controlled and uncontrolled cooling rate on motility parameters of cryopreserved ram spermatozoa. BMC Research Notes 2011, 4:547.

\section{doi:10.1186/1756-0500-5-319}

Cite this article as: Ashrafi et al:: Retraction: Effect of controlled and uncontrolled cooling rate on motility parameters of cryopreserved ram spermatozoa. BMC Research Notes 2012 5:319.

\footnotetext{
*Correspondence: i.ashrafi@ut.ac.ir

${ }^{1}$ Young Researchers Club, Science and Research Branch, Islamic Azad
} University, Tehran, Iran

Submit your next manuscript to BioMed Central and take full advantage of:

- Convenient online submission

- Thorough peer review

- No space constraints or color figure charges

- Immediate publication on acceptance

- Inclusion in PubMed, CAS, Scopus and Google Scholar

- Research which is freely available for redistribution

Submit your manuscript at www.biomedcentral.com/submit

C Biomed Central

\section{Ciomed Central}

